\title{
THE IMPACT OF TYPE OF INDUSTRY, COMPANY SIZE AND LEVERAGE ON THE DISCLOSURE OF CORPORATE SOCIAL RESPONSIBILITY Case on Companies listed in Indonesia Stock Exchange 2009-2012
}

\author{
V.Mardi Widyadmono \\ Universitas Sanata Dharma \\ v_mardi_w@yahoo.com
}

\begin{abstract}
Many scholars are interested in the disclosure of corporate social responsibility (CSR). Several international publications proves that the disclosure of corporate social responsibility is determined by type of industry, company size, and leverage. There are few CSR research conducted in the Indonesian context. This research is conducted to give perspective on Indonesia companies disclosing their corporate social responsibility. Understanding how Indonesian companies are disclosing their corporate social responsibility will help the government in encouraging them to implement their CSR according to the regulations. 86 companies listed on Indonesia Stock Exchange (IDX) in the year of 2009-2012 were choosen under purposive sampling technique. Regression analysis, $F$ test and t test were used to examine factors influencing the company disclose of their corporate social responsibility. The results indicate that type of industry, company size and leverage have an influence on the disclosure of CSR. It is providing evidence that most of the Indonesian companies operating in Indonesia perceive that corporate social responsibility has only benefit in the long run and little advantage in the short term.
\end{abstract}

Keywords: Corporate Social Responsibility, Type of Industry, Company size, Leverage.

\begin{abstract}
Abstrak
Banyak peneliti tertarik pada pembukaan informasi tanggungjawab sosial perusahaan (CSR). Beberapa publikasi internasional membuktikan bahwa disclosure tanggungjawab sosial perusahaan ditentukan oleh tipe industri, ukuran perusahaan, dan leverage. Namun, hanya sedikit riset-riset tanggungjawab sosial perusahaan (CSR) yang diterapkan pada konteks Indonesia. Penelitian ini bertujuan untuk memberikan perspektif pada perusahaan-perusahaan Indonesia yang membuka informasi mengenai tanggungjawab sosial perusahaan mereka. Memahami bagaimana perusahaan-perusahaan Indonesia membuka informasinya mengenai tanggungjawab sosial perusahaan akan membantu pemerintah dalam mengimplementasikan program-program CSR yang sesuai dengan aturan undang-undang. Sebanyak 86 perusahaan yang terdaftar di Indonesia Stock Exchange (IDX) dalam rentang 2009-2012 dipilih melalui teknik sampling purposive. Analisis regresi, uji-F, dan uji-t digunakan untuk menguji faktor-faktor yang memengaruhi perusahaan dalam mendisclosure informasi mengenai tanggungjawab sosial perusahaan mereka. Hasil analisis menunjukkan bahwa tipe industri, ukuran perusahaan, dan leverage memiliki pengaruh pada disclosure tanggungjawab sosial perusahaan. Hasil tersebut juga memberikan pengertian bahwa sebagian besar perusahaan Indonesia yang beroperasi di Indonesia mempersepsikan program-program CSR hanya memiliki manfaat jangka panjang dan sedikit keuntungan/manfaat pada jangka pendek.
\end{abstract}

Kata kunci: tanggungjawab sosial perusahaan, tipe industri, ukuran perusahaan, dan leverage

\section{INTRODUCTION}

In the traditional perspective, all companies are set up and operated for the welfare of the owners. Whatever the type of company (soleproprietorship, partnership, or corporation), they are dedicated to enhance the companies' value. The higher the companies' value, the higher the owners' welfare. Brigham and Houston wrote that, "the ultimate goal of managers are to maximize the stock price. Though they still have to 
consider ethics in the way the companies pursue this goal." (Brigham \& Houston, 2013:10).

Recently, the responsibility of companies to their community begins to be seen in a different perspective. The community surounding the companies may understand that the responsibility of the company encompass all efforts to enhance the community quality of life through initiating and accomodating efforts that benefit most of the community. McWilliams and Siegel (2001:117) said, "actions on the part of a firm that appear to advance the promotion of some social good beyond the immediate interests of the firm/shareholders and beyond legal requirements". The awareness that a company is a part of the larger community is the basis of corporate social responsibilty (CSR) policy and activity.

Milton Friedman was one of a few writers who refused to support the practise of CSR. He said that only single individuals can assume the responsibility not the business. Newell Hampson-Jones cited this perspective in an online article. http://grenobleem.academia.edu/nhj

"If we wish we can refer to some of these responsibilities as 'social responsibilities.' But in these respects he is acting as a principal not an agent; he is spending his own money or time or energy, not the money of his employers or the time and energy he has contracted to devote to their purposes. If these are 'social responsibilities,' they are the social responsibilities of the individual, not the business."(Friedman, 1970: 2)

This discussion on CSR has evolved over time in order to reveal the true meaning of CSR. If more and more people agreed with Friedman's perspective that only people assume the responsibility not the business, then it will be useless to continue sounding the depths of CSR. Fortunately, the main stream public support for CSR is becoming stronger. Many people begin to realize that corporate social responsibility could help a company reach its ultimate goal, that is profits. For example, Porter and Kramer (2002:1) put CSR on the strategic level in the company. They wrote that CSR benefits an organization strategically. Figure 1 depicts the potential benefit the com- pany might have from praticing CSR. (Hawkins, 2006:191).

There are several regulations in Indonesia that govern how companies should deal with the CSR issue. These laws include: The Republic of Indonesia No 25 of 2007 on investment, No 40 of 2007 on Limited Liability Company, Decision of the Ministry of State Owned Corporation No. Per 05/MBU/2007 on the partnership with Small Enterprises and Environment. Indonesian legislation No 40 of 2007 in article No. 74 explicitly described how companies operating in Indonesia territory should dedicate their efforts in corporate social responsibility projects, specifically stating: (1)The Company having its business activities in the field of and/or related to natural resources, shall be obliged to perform its Social and Environmental Responsibility; (2)Social and Environmental Responsibility as referred to in paragraph (1) shall constitute the obligation of the Company which is budgeted and calculated as the cost of the Company, implementation of which shall be performed with due observance to the appropriateness and fairness; (3)The Company which fails to perform its obligation as referred to in paragraph (1) shall be imposed with sanction in accordance with the provision of regulation. Ideologically, the government of Indonesian Republic has declared how the company should implement its CSR program. State owned Companies (BUMN) are expected to be the leader in tackling the CSR issues and its implementation. Conceptually, this initiative should be viewed as model for companies operating in Indonesia.

Historically, the research on the disclosure of corporate social responsibility have shown an inconsistency. Hackston and Milne's (1996) research for example, demonstrated that company size and industry type have a significant correlation to corporate social responsibilty disclosure. Fitriani (2001) and Sembiring (2005) found other variables namely, company profitability, the size of board of commissoners, and company profiles that influence the disclosure of CSR. On the contrary, Anggraini (2006) and Fathurohmi (2010) could not find any evidence that company size and the size of board of commissoners influence CSR disclosure.

This research is conducted to assess the impact of indutry type, company size and leverage using a longer period of time (2009-2012). 
Previous research used only a one year period. The industry type classification is based on whether a company's profile either high or low. This classification originated from the work of Edwin Mirfazli (Mirfazli, 2008). High profile companies are those companies that its operation directly exploit the natural resources and have impact on environment and community e.g mining company. While low profile companies are those companies that do not use natural resources directly like beverages company, garment company and trading company. Company size is approached from its assets. Finally, for the leverage, a ratio of company loans is considered against its assets.

\section{LITERATURE REVIEW}

Business sustainability nowadays becomes a hot topic of debate in business and management. The fast changes in business and economics in a broader sense, are assumed as new threats for the existence of business. Businesses that fail to accomodate these changes will vanish from the economy. Maurice Berns et al. (2009) is one of many researchers who propose that company sustainability is very essential for the fulfiling of the triple bottom lines that include economics, environment, and social impacts. John Elkington (1997: ??) was the one who introduce the spirit of CSR in the business operation. He stated that to pursue business profit, corporations should also demonstrate positive contributions to society (people) and actively participate in conserving the environment (planet). This implies that companies are supposed to do CSR, if they wish to stay in the business.

\section{Corporate Social Responsibility}

Ultimately, companies are doing business for profits. It is unavoidable that their process of providing goods and services have impacts on its environment. This reality encourages every single company to consider the impact of its decisions on the external and internal stakeholders. This awareness shapes what we called corporate social responsibility. CSR is perceived as an integrated part of the whole business operation. When the business completely integrates the CSR, this business operates beyond the regulation, and the sustainability of the business is guaranteed in the long run.
Madura (2007) in his research described the responsibility of firms to its stakeholders, that is to customers, stockholders, employees, creditors, community, and the environment. The responsibility to most of these is clear except the last two. The business' responsibility for the community and environment is often considered vague. For example, when a firm declares we care about our community, which community does that firm really mean? This ambiguity is not clear enough to justify. Similar with the responsibility for the environment, the pros and cons in this issue become more severe in terms of impact and sustainability. Several researches have been conducted to justify the urgency of firms to fulfill these CSR responsibilty (Kapoor \& Sandhu, 2010; Flammer, 2013; Manshoor \& Khan, 2013). Shermerhorn (2012: 74) in his textbook of Exploring Management describes two perspectives of corporate social responsibility, namely the classical view and the socioeconomic view. The classical view mentioned that the responsibility of a company is limited to increasing the value of the company or sound financial performance. It is in line with the thought of Milton Friedman. The financial performance is the only measurement of the success of a company. While the latter socioeconomic view broadens the focus of a company. Not only will companies pursue corporate profits, a company should fulfill its obligation to enhancing the social welfare.

Considering the most basic knowledge in decision making process, an individual's morality will have impact on the decisions a company makes. Robbins and Coulter (2012: 130) explained that the company's decision to engage in social activities is more influenced by the managers. When the decision makers has reached successive stage, an individual's moral judgment becomes less dependent on outside influences and more internalized. Thus, when a company faces the environmental issues, air pollution for instance, the morality of the manager will influence the process of making a decision. Robbins and Coulter (2012:131) cited from Kohlberg's work on "Moral Stages and Moralization: The Cognitive Development Approach" to elaborate this morality. He accentuated that human in their life follows stages in its morality development as depicted below. It starts from pure sticking to rule to avoid physi- 
cal punishment and end up at sixth stage when someone live his/her ethical principles even if he/she violate the law.

Eventhough the agency theory assure us that managers tend to make any decision according to their interest, their morality development stage will guide them in making a decision. The problem is that we do not have any idea at what stage is our manager right now. Understanding this morality development stage will help justify the phenomena of disclosing CSR in Indonesia (Robbins and Coulter, 2012:131).

Eventhough the discussion has not reached an ultimate conclusion, there are several evidences that the implementation of CSR will lead to a higher financial performance. Legally, the Indonesian Government has regulated the practise of corporate social responsibility (UU no $25 \& 40$ tahun 2007). Corporations that are doing business in Indonesia have followed this regulation according to their different perspective. Since that year, corporations listed in IDX began reporting its corporate social responsibility activites in the annual report. There is no guidance in reporting these activities. Hence, there is diversity in the ways of reporting CSR.

Companies are mandated to provide annual report. Generally, companies focus their report on their financial performance. This annual report helps the stakeholders in decision making according to their role within the company. The quality of the annual report is very important. Of course, the quality justification depends on the interest of the stakeholders. To investors, for instance, the clarity of all financial corporate performance in the annual report will help them to decide whether to buy or sell their stocks.

In today's world, the stakeholders do not just pay attention to the financial performance in making decisions. They need more than the financial reports. In the investment decision, investors begin to consider the role of company for the goodness of society. Thus, there is a strong demand for the company to put more non-financial information in their annual report. Arvidsson (2011: 278) said clearly, "Thus, in order to overcome the insufficiency of financial statements and obtain the above benefits, companies are urged to improve their disclosure on intangible assets". Disclosure of cor- porate social responsibility should include intangible assets or a non financial performance.

There are three approaches in disclosing the annual report to fulfill the demand of the stakeholders. They are: adequate disclosure, fair disclosure, and full disclosure. This reflects the scope and the depth of the annual report. The adequate disclosure determines that the disclosure is fine when it satisfies the minimum requirements set by the law. More than this approach, fair disclosure assumes the ethical perspective. This approach urges the company to provide fair information for the investors to value the company. And the latter approach, full disclosure ensures the company fully makes available information regarding the economic events relating to the company. Consequently, it is mandated for the companies to explicitly inform the potential readers of annual report of all events that either directly or indirectly influence the condition of the company.

Polinsky and Shavell (2010) tried to explain another side of disclosure of information in annual reports. Under mandatory disclosure, companies are forced to assert all relevant information for the customers, but often a company will avoid providing information that harms the company position. When the information regarding CSR is considered as voluntary disclosure and not yet a mandatory obligation, the company tends to declare only the information that benefits the company and will often hide information that is harmful to image of the company.

\section{Type of Industry}

Mirfazli (2008:39?) in his work on the disclosure of corporate social responsibility classified companies into high and low profile industries. The high profile industry consisted of companies that directly exploit the natural resources from the environment. The mining company is one example of this high profile industry. Oppositely, the classification of low profile industries is comprised of companies that do not exploit the natural resouces directly. The examples of this low profile group are contruction and property company, banking company, medical suppliers, textile company, personel, and home product manufacturer, and others. Generally, the society has a high sensitivity for the high profile company because people are concerned with the sus- 
tainability of the natural resources and protection of the environment. This classification of Mirfazli (2008) will be used in this research to investigate the tendency of companies in disclosing its corporate social responsibility.

Utomo in Ayuna (2008) conducted a research on companies listed in IDX 1998 regarding the pattern of social disclosure namely: theme, type, item, and its location in the annual report based on the high profile and low profile classification. The difference between high and low profile is in the company's sensitivity to the environment. Utomo found a limited number of corporate social responsibility practices reported in the annual report. It reflected the situation where companies failed to utilize the annual report as a means of communication between management and the stakeholders. This research demonstrated that high profile companies disclose more information on the corporate social responsibility projects than the low profile companies. On the contrary, Suripto (1999) reported from his research that type of industry did not influence the voluntary disclosure in the annual report.

Currently, research has revealed that there is a systematic relationship between the type of industry and CSR disclosure. Society in general assumes that the companies exploiting directly the natural resources should be responsible with the environment and the surounding communities. They want the companies to respect the rights of those communities especially when it relates to the comercial use of unrenewable natural resources. The companies that fall in to this high profile industry tend to run the corporate social responsibility programms and describe them in their annual report.

\section{Company Size}

There are specific determinants of company decision to adopt corporate social responsibility in its operation. Udayasankar (2007:??) stated in his work that the relation between company size and CSR decisions makes a U-shape. Companies that are categorized under big and small company tend to adopt CSR, while the medium size companies do not show a similar tendency. The term big company refers to those that have enough financial resources to initiate CSR projects. Similar to the views of DuBrin (2012: 92) in his work, companies with large financial resources will afford the investment needed in CSR initiatives. He demonstrated that there is a reciprocal influence between social responsibility and profits. When companies gain more profits, they could invest in CSR initiatives. In turn, the implementation of these CSR initiatives will lead to more profits for the companies. This result is what is then called as the virtuoso cycle, where corporate social performance and corporate/financial performance feed and reinforce each other.

Researchers often justify the company size based on a certain numerical basis, like its number of employees or other measurements. Ferry and Jones (Sujianto, 2001) used assets and sales as a basis for classifying the company size. Using assets as the basis for classifying the company, will help us to see the relation between the size of financial resources available and the disclosure of CSR. Generally, communities expect that companies with abundant resources will develop their surrounding area and hinder the hazards that are raised from the companies operations. Thus, the overall information regarding the CSR initiatives will complete the annual reports. Most of the time the disclosure of CSR is classified as voluntary disclosure. This disclosure of CSR can strengthen the company's image and finally will have a positive impact on its stock price.

\section{Leverage}

Leverage is a financial performance measurement that was used in this research, utilizing a ratio of company loans and its total assets (debt to equity ratio). This measurement attempts to provide information on how a company finances its assets whether by loan or internal financing. Companies with a high leverage are potentially able to make a broader voluntary disclosure. Ideally and essentially, they are exposing their positive image to the stakeholders.

However, it is possible that a company with high leverage does not make any CSR program. They prioritize their obligation to the creditors and reduce its budgets for the social cause. Usually, a firm finances its CSR projects from its earnings, meaning the firm reduces its earnings for the social cause, instead of paying back its loans to creditors. To avoid the negative perceptions of the creditors, the companies might omit CSR in its report. Belkaoi and Karpik (1989) affirm that the higher leverage ratio, 
the larger the probability of company to disregard the credit terms. The company will make sure that the company is able to fulfill their obligation to pay back its loan. One of many ways to make this result happen is by reducing the expense of running CSR programs. Consequently, the company tends to report the higher financial performance rather than the exposing of CSR initiatives.

\section{THEORITICAL FRAMEWORK AND HYPOTHESIS}

\section{The Type of Industry and The disclosure of corporate social responsibility}

The relation between type of industry and disclosure of corporate social responsibility has been confirmed from several researches. In the Indonesian context, the research on this topic is still limited. Mirfazli (2008), for example, in his research classified industries into basic and chemical companys and in the variety companys. Then, Mirfazli identified the basic and chemical industries as high profile company, and the variety company as the low profile company. Hence, he extended the scope of classification to propose that the company exploiting more on the natural resources and impacting on the society to be the high profile company, such as mining companies, pulp, and chemical producers. In comparison, low profile company provides daily need items, such as beverages, garments and retail business products. Logically, the company that directly utilizes the natural resources in its business, it should do more CSR projects. Theoretically, the company owes the natural resources from the society and it should return them in the form of goodness for the society. Ethical managers will show this morality when they encourage a company to pursue CSR programs, while the low profile company will have a less demanding public about this concern because they do not directly utilize the natural resources from the society. In the broader sense, managers on behalf of the stockholders are demanded to behave appropriately with the social norm. Suchman (1995: 574) definitely stated it as legitimacy theory.

Legitimacy is a generalized perception or assumption that the actions of an entity are desirable, proper, or appropriate within some socially constructed system of norms, values, beliefs, and definitions.

Obviously, companies that exploit natural resources and potentially harm the environment must consider the surounding communities. In line with the legitimacy theory, Cuganesan et al. (2007) found that companies who are considered to be more 'high profile' than others are likely to disclose more CSR information than those considered to be lower in profile.

$\mathbf{H}_{\mathbf{1}}$ : The type of Industry influence the disclosure of corporate social responsibility

The company size and the disclosure of corporate social responsibility

Udayasankar (2007) found that the distribution of company size and corporate social responsibility disclosure form a U-shaped graph. Basically, both companies classified as big and small provide more information regarding the implementation of CSR compared to the medium size company. Kunianto (2007) revealed in his research that the larger company tends to have relatively more activity in CSR because they have sufficient funds to finance them. Thus, disclosing corporate social responsibility becomes an easy task for them. Faturohmi (2009) conducted a research related to company size and corporate social responsibility disclosure. He found that companies with larger size reported more on CSR in its annual report. Based on this fact, this research proposes the following hypothesis.

$\mathbf{H}_{2}$ : The size of company influences the disclosure of corporate social responsibility

\section{The Leverage and and The disclosure of CSR}

The leverage ratio is the ratio of total debts to total equity. This ratio describes the firm's capital structure, where creditors can see the possibility of losing their investments. The higher the ratio, the higher probability of losing their money. Schipper in Marwata (2000) stated that additional information is needed in order to reduce the doubt of creditors concerning their money in the firm. The implication is the higher leverage company will limit their CSR activity and hence, only provide limited CSR report in its annual report (Belkaoui \& Karpik 1989). The leverage could vary the disclosure of CSR. 
Based on this fact, the second hypothesis proposes:

$\mathbf{H}_{3}$ : The leverage influences the disclosure of corporate social responsibility

\section{RESEARCH METHOD}

\section{Population and Sample}

The population of this study includes all companies listed on the Indonesia Stock Exchange in 2009 - 2012, as published in the Indonesian Capital Market Directory (ICMD). The samples in this study were selected using purposive sampling. The following four sampling criteria served as determiners in choosing the research sample: a) They are companies that published full financial statements (including the notes to the financial statements) and annual reports through the web site of Indonesia Stock Exchange during 2009-2012. b)They are companies that include the corporate social responsibility report in the annual report during 20092012. c) They are companies that report a positive profit after tax during 2009-2012.

\section{Variables Measurement}

\section{Dependent Variables}

The dependent variable in this study is social responsibility disclosure (CSR). It is measured using a search instrument in the form of a check list of corporate social disclosure and the expected number of items disclosed from the company ( $\mathrm{n}=78$ items), based on the check list this statistic was then calculated for the CSR disclosure index. This 78 items originated from the regulation of Indonesia Capital Market and Financial Institution Supervisory Agency. CSR Index = number of CSR items disclosednumber of CSR item expected

\section{Independent Variables}

Independent variables are measured as follows.

1. Industry Profile Variables

Industry Profile variables uses dummy variables to classify high profile and low profile. 1 rated high profile and low profile industry was given a value of 0 .

2. Company size Variables

Company size in this study is measured by the value of assets owned as shown in the financial statements of the company during 2009-2012.
3. Leverage

Leverage were measured by divided total debt to equity ratio (DER).

DER=Total DebtTotal equity

\section{Statistic Tools}

Several statistic tools were used in order to asses the relation between dependent and independent variables. The regression analysis is one that is used to verify the hypothetical propositions. Since this research is using more than one independent variabels, multiple regression analysis will be used with the following equation model.

\section{$\mathrm{CSR}=\alpha+\beta 1 \mathrm{TI}+\beta 2 \mathrm{SIZE}+\beta 3 \mathrm{DER}+\varepsilon$}

legend:

CSR = The disclosure of corporate social responsibility is measured by CSR index measured by the CSR index, the number of items disclosed divided by the number of items that should be disclosed.

$\alpha=$ Constanta

$\beta_{1 \ldots . .5}=$ Regression Coeficient

SIZE $=$ Firms Size

$\mathrm{TI}=$ Industrial Profile

DER $=$ Debt to equity ratio

$\varepsilon \quad=$ residual

The other statistic tools employed are the F test and $t$ test. F-test is used to determine the suitability of the regression model. The t-test is applied to determine the effect of the independent variable (the type of industry, company size, and leverage) on the dependent variable that is the disclosure of CSR. Coefficient of determination value is used to assess the ability of a model to explain the variability of dependent variable.

\section{RESULTS}

\section{Research Samples}

The research population was all the companies listed in the Indonesia Stock Exchange (IDX) during 2009-2012. The researchers used purposive sampling method to build the research sample. Based on the predetermined characteristics, the following research sample resulted. 
Table 1: Number of Samples

\begin{tabular}{lc}
\hline \multicolumn{1}{c}{ Classification } & Amount \\
\hline Number of companies that could be accessed via IDX web & 317 \\
Number of companies disclosed CSR in the annual report in 2009 -2012 & 156 \\
Number of companies reported losses. & $(66)$ \\
Number of companies that its annual report cannot be accessed completely & $(4)$ \\
Total number of research samples & 86 \\
Number of data processed & 344 item \\
\hline
\end{tabular}

\section{Description of Data}

The number of companies that meet the predetermined criteria is 86 firms with various characteristics. Based on type of industry, 44 companies fall into high-profile, while 42 companies fall into low profile. The number of company that disclose CSR in a separate chapter from the financial report during $2009-2012$ is 19 companies. Meanwhile, 14 companies do not disclose CSR. The number of companies that its CSR disclosure item increases each year is 33 companies. 2 companies report the same number of item. Finally, 51 companies report in an unstable number of items. This portrait reflects that there is no yet the general pattern in reporting the CSR activities in the annual report.
The collected data shows the index of CSR that is determined by calculting the ratio of the number of items reported in the annual report and the standard of 78 items. The data summary is depicted in Table 2 .

The data shows that $81,4 \%$ of the research sample companies do not disclose enough their corporate social responsibility projects in the annual report. 7 companies demonstrate their willingness to assert the corporate social responsibility. In terms of amount of information provided in the annual report, they declare more information compared to moderate and low category.

To find out more detail about the company which report the corporate social responsibility projects, a crosstab of the index with the industry type is depicted in Table 3.

Tabel 2: CSR INDEX

\begin{tabular}{lrrrr}
\hline Category & Frequency & Percent & Valid Percent & Cumulative Percent \\
\hline Low & 70 & 81.4 & 81.4 & 81.4 \\
Moderate & 9 & 10.5 & 10.5 & 91.9 \\
High & 7 & 8.1 & 8.1 & 100.0 \\
Total & 86 & 100.0 & 100.0 & \\
\hline
\end{tabular}

Table 3: Profile * CSR Rating Crosstabulation

\begin{tabular}{llrrrr}
\hline \multirow{2}{*}{ Profile } & \multicolumn{4}{c}{ CSR Rating } \\
\cline { 2 - 5 } & \multicolumn{1}{c}{ Low } & Moderate & \multicolumn{1}{c}{ High } & \multicolumn{1}{c}{ Total } \\
\hline \multirow{5}{*}{ Low Profile } & Count & 40 & 1 & 3 & 44 \\
& \% within Profile & $90.9 \%$ & $2.3 \%$ & $6.8 \%$ & $100.0 \%$ \\
& \% within Cat_CSR & $57.1 \%$ & $11.1 \%$ & $42.9 \%$ & $51.2 \%$ \\
& Count & 30 & 8 & 4 & 42 \\
& \% within Profile & $71.4 \%$ & $19.0 \%$ & $9.5 \%$ & $100.0 \%$ \\
& \% within Cat_CSR & $42.9 \%$ & $88.9 \%$ & $57.1 \%$ & $48.8 \%$ \\
& Count & 70 & 9 & 7 & 86 \\
& \% within Profile & $81.4 \%$ & $10.5 \%$ & $8.1 \%$ & $100.0 \%$ \\
& \% within Cat_CSR & $100.0 \%$ & $100.0 \%$ & $100.0 \%$ & $100.0 \%$ \\
\hline
\end{tabular}


This research demonstrates that 70 out of 86 companies $(81,4 \%)$ provide less information regarding the CSR projects in their annual report. The average CSR index is 0,202. This statistic means that companies listed in IDX (2009-2012) disclose only two out of 10 items from the expected items to disclose. More surprisingly, out of 42 companies that are included in high profile company, only $4(9,5 \%)$ companies reported more amount information on corporate social responsibility and its disclosure of them. These high profile companies, because they operate directly on the natural resources, are supposed to do CSR programs in order to suppress the level of damage that may come from its operation. However, to date, $71 \%$ of them report only a little amount of information concerning CSR. In contrast to the findings in a Spanish study, Reverte (2009) concluded that the high rating in disclosing corporate social responsibility is found in companies which are socially and environmentally sensitive. The high profile company in Indonesia that socially and environmentlly sensitive should learn from these Spanish companies. Since they are able to demonstrate that being a socially and environmentally sensitive company means practising more CSR.

In the perspective of agency theory, managers as a person in charge of the company hold the authority to make the CSR projects beyond the regulation or choose to only fulfill the minimum requirements. Such managers, according to Robbins and Coulter (2012), fall into the conventional managers, who do the CSR as long as they agreed upon the projects. At least, this approach would be better than doing the CSR in order to avoid the punishment if they fail to follow the CSR regulations (preconventional stage).

The companies which do not have such a strong obligation to do social responsibility, however, choose not to conduct the CSR projects $90.9 \%$ or 40 low profile companies report little if any information on CSR, which does make some logical sense. They can not see the direct relation between the expense of CSR and the profit for the company. If they conduct a corporate social responsibility project, it would be very limited in scope and amount of money involved. Therefore, they have just a limited information on the CSR or nothing to report in their annual report.

Furthermore, there is an explanation why the CSR rating showing a pattern of low tendency. CSR activities need a considerable amount of money and resources. Managers recognize that this dedicated amount of money and resources will not benefit the company directly. Certainly, they perceive these projects as a big burden for the company. It would be better for all managers to put the investment in the other projects that will potentially benefit the company. When classifying the assets the companies have into large, medium, and small, 97\% of those companies fall into the small company (Table 4), which means the companies reported such a limited resources and fund, that they can not afford the cost for doing the CSR projects. As a result, the small companies tend to have limited CSR projects if any. Potentially, the companies perform the CSR projects only for satisfying the government legislation. This finding confirms the findings of Udayasankar (2007) that the smaller the company, the less CSR projects it initiates.

Table 4: Assets * CSR Crosstabulation

\begin{tabular}{|c|c|c|c|c|c|}
\hline \multirow{2}{*}{\multicolumn{2}{|c|}{ Assets }} & \multicolumn{4}{|c|}{ CSR Rating } \\
\hline & & Low & Moderate & High & Total \\
\hline \multirow[t]{3}{*}{ Small } & Count & 68 & 9 & 7 & 84 \\
\hline & $\%$ within Assets & $81.0 \%$ & $10.7 \%$ & $8.3 \%$ & $100.0 \%$ \\
\hline & $\%$ within Cat_csr & $97.1 \%$ & $100.0 \%$ & $100.0 \%$ & $97.7 \%$ \\
\hline \multirow[t]{3}{*}{ Large } & Count & 2 & 0 & 0 & 2 \\
\hline & $\%$ within Assets & $100.0 \%$ & $.0 \%$ & $.0 \%$ & $100.0 \%$ \\
\hline & $\%$ within Cat_csr & $2.9 \%$ & $.0 \%$ & $.0 \%$ & $2.3 \%$ \\
\hline \multirow[t]{3}{*}{ Total } & Count & 70 & 9 & 7 & 86 \\
\hline & $\%$ within Assets & $81.4 \%$ & $10.5 \%$ & $8.1 \%$ & $100.0 \%$ \\
\hline & $\%$ within Cat_csr & & $100.0 \% 100.0 \%$ & $100.0 \%$ & $100.0 \%$ \\
\hline
\end{tabular}


Most of the companies in this research $(97,7 \%)$ fall into small company category, in terms of assets they reported in their annual report. $81 \%$ of them have a low rating in CSR. This facts suggests that managers will prevent the company from investing in something that is not profitable since the performance of managers is measured mostly from their capability to increase the company's profits.

\section{Testing the Hypothesis}

a. F test Result

$F$ test is used to determine the simultaneous effect of independent variables on the dependent variable. $F$ test results can be used to verify the fitness of the model suggested. $\mathrm{F}$ test result in Table 5 shows that the $\mathrm{F}$ value of 34.759 with the significance level of 0.000 . The significance level is far below the alpha of $5 \%$. This statistic indicates that three independent variables, namely industry type, company size and leverage, simultaneously affect the dependent variable (CSR).

b. Test of Coefficient Determination ( $R$ square) The computed values of R Square of 0.284 , which means that the variations of the de- pendent variables affected by the independent variable and the remaining $71,6 \%$ is influenced by other variables that are not included in the research model.

\section{c. t Test Result}

Table 7 shows that the significance value each independet variable is below the alpha of $5 \%$. It indicates that type of industry, company size and leverage individually influence the dependent variable (CSR). The first hypothesis which states the type of industry influence the CSR disclosure is accepted. The p-value for type of industry of 0000 is below the alpha of 0,05 . The second hypothesis which states that the size of the company influence the disclosure of CSR is accepted. The $p$ value for company size of 0000 is below the alpha of 0,05 . The last hypothesis which states that the leverage of the company influence the disclosure of CSR is accepted. The p-value for leverage of 0.000 is below the alpha of 0.05 . In short, the three independent variables contributes individually to the variation of the disclosure of corporate social responsibility.

Table 5: F test Result

\begin{tabular}{llllll}
\hline Model & Sum of Squares & df & Mean Square & F & Sig. \\
\hline $1 \quad$ Regression & 3.438 & 3 & 1.146 & 34.759 & $.000^{\mathrm{a}}$ \\
Residual & 8.670 & 263 & .033 & & \\
\multicolumn{1}{l}{ Total } & 12.108 & 266 & & & \\
\hline
\end{tabular}

a. Predictors: (Constant), LEVERAGE, SIZE, PROFILE

b. Dependent Variable: INDEKS

Table 6: R Square Test Result

\begin{tabular}{|c|c|c|c|c|}
\hline \multicolumn{5}{|c|}{ Model Summary $^{\mathbf{b}}$} \\
\hline Model & $\mathrm{R}$ & R Square Adjusted R S & quare Std. Error of the Esti & Durbin-Watson \\
\hline 1 & $.533^{\mathrm{a}}$ & $.284 \quad .276$ & .18156734829 & .886 \\
\hline \multicolumn{5}{|c|}{ a. Predictors: (Constant), LEVERAGE, SIZE, PROFILE } \\
\hline
\end{tabular}

Table 7: $t$ Test Result

\begin{tabular}{|c|c|c|c|c|c|c|}
\hline \multirow{2}{*}{\multicolumn{2}{|c|}{ Model }} & \multicolumn{3}{|c|}{ Unstandardized Coefficients Standardized Coefficients } & \multirow{2}{*}{$\mathrm{t}$} & \multirow{2}{*}{ Sig. } \\
\hline & & $\mathrm{B}$ & Std. Error & Beta & & \\
\hline \multirow[t]{4}{*}{1} & (Constant) & .199 & .020 & & 9.905 & 5.000 \\
\hline & PROFILE & .088 & .023 & .206 & 3.887 & 7.000 \\
\hline & SIZE & $6.072 \mathrm{E}-9$ & .000 & .383 & 7.335 & 5.000 \\
\hline & LEVERAGE & -.043 & .007 & -.351 & -6.631 & 1.000 \\
\hline
\end{tabular}




\section{Discussion}

The high profile company is a company that directly utilizes the natural resources in its operation. Such high profile companies will get more attention from the society because its potential of producing a harmful impact on the environment. To compensate for its potential damage, the government is using its legislation to demand those companies to develop its social responsibility through CSR projects. Like the legitimacy theory, a company will have its legitimacy to do its business as long as they run the business in accordance with the values the society lives.

The test results showed that the type of industry that are classified as "high profile" and "low profile" has a p-value of 0.000 , which is statistically significant because the value is much smaller than the alpha level of 0.05 . Therefore, the statistic supports the hypothesis that the type of industry influences disclosure of corporate social responsibility. In general, the Indonesian government through its legislation have encouraged limited liability companies to create and report their CSR activities. After the regulation launched, the number of companies who reported the CSR activities in its annual report increased. Eventhough, according to this research only the high profile company usually disclose its corporate social responsibility activities, which makes sense because the company that directly utilizes the natural resources and environment will face pressure from the surrounding community, NGO and others who are concerned with the sustainability of the environment. Furthermore, this disclosure of CSR may provide such a positive image that stakeholders believe the company really care with the environment. Finally, a rise is expected expected in the company stock price in the stock market. This finding is in line with the research conducted by Faturohmi (2006) which examines the influence of corporate characteristics on the voluntary disclosure of CSR in their annual report. The study proved that statistically, industry profiles affected the company's extensive voluntary disclosure.

The crosstab between the type of industry and the index of CSR shows that only a small number of high profile companies $(9.5 \%)$ have a high rating in the CSR index in contrast to $71.4 \%$ which is in low rating. Eventhough, $71,4 \%$ of high profile companies provided a small number of CSR information in their annual report, this study demonstrates that the influence is positive. The tendency of increasing the CSR information is shown over time. The managers of high profile companies are responsible to make this pattern true. It is not surprisingly, the Indonesia government begins regulating the corporate social responsibility only in the year of 2007 , since it takes time to have all companies embrace the policy of CSR and apply it to the community. In addition, the government should prepare the minimum requirement for the company in conducting CSR projects with regard to the company profile. We need to convince all managers that CSR activities will bring a positive impact both for the company and the society as well. Unlike in what Galbreath (2010) found in Australia, where the research revealed that Australian companies practising corporate social responsibility benefit in terms of reducing labor turnover, increasing customers satisfaction and increasing the company reputation. The awareness of managers in Australian company is high enough to embrace the corporate social responsibility as a part of the company strategy. Porter and Kramer (2002:3) had proposed how to incorporate CSR in the company strategy. They explained CSR this way. "Through contextfocused philanthropy, corporations provide money, capabilities, and partnerships to charitable causes in ways that sharpen their own competitive edge. They generate social-and economic-benefits far exceeding those provided by individuals, foundations, or governments".

The test to assess the effect of firm size on CSR disclosure shows the p-value of company size is 0,000 . This value is considered significant because it is smaller than the value of alpha (0.05). The test result indicates a positive value. Hence, the larger the company's asset, the more company disclose its corporate social responsibility projects in the annual report. Companies with large assets have more access to resources needed to finance the corporate social responsibility projects. In addition, with the character of increasing environmental sensitivity, the company could utilize these CSR projects to inform the world that they care for the environment. By doing this, 
the companies will get a legitimacy for continuing their operation.

Hence, more and more social activities are run and the more CSR are disclosed in the financial statements (Lauren, 2010). Larry and Jones in Sujianto (2001) concluded that the limited liability companies with larger size tend to inform more corporate social responsibility activities, including voluntary disclosure. This disclosure will enhance the company's image, which in the long run, will affect the stock prices in the market. This result is consistent with the research of Faturohmi (2008), Sari (2009) and Kunianto (2009). Different from the current study, the last three researches used data from only one year period of observation.

Essentially, the smaller amount of assets, the smaller access for the company to finance the social projects. Moreover, if the company is a low profile company - that is not enviromentally sensitive - the company will have a reason to organize a CSR project. On the other hand, Udayasankar (2007:2) stated that "the smaller company, meaning less assets, often have constrained or inadequate access to resources which may make it unviable for them to engage in corporate social responsibility initiatives".

The test results for the influence of leverage on the disclosure of CSR indicates that the leverage influences the disclosure. This support for this hypothesis is evident statistically from the $\mathrm{p}$ value that is lower than the alpha of $5 \%$. The coeficient sign is negative, which means that the higher the leverage, the less probibility they will disclose the CSR activities. Yintayani (2011) found the similar conclusion in her thesis. A high leverage company implies that the debt value of the company is close to the value of assets. The company has more obligation to pay for the creditors. In the annual report, the company tends to inform all information necessary to guarantee that the creditors will get their money back. Schipper in Marwata (2000) affirmed that additional information is needed in order to reduce the doubt of creditors concerning their money in the firm. Consequently, the company prefers to satisfy the needs of its creditors rather than to satisfy the society that is not as clear of an entity. Social and environmental information is often considered not relevant for the creditors. The implication is the higher leverage company will limit their CSR activity and hence, have only limited, if any, CSR to report in its annual report (Belkaoui \& Karpik 1989). This fact can help explain the tendency of high leverage companies who do not provide information regarding its social activities.

\section{Conclusion}

Discussing CSR and its disclosure in annual reports demonstrates that a company as an entity is also a citizen in a broader society. It is the role of managers to make the company to be a good citizen or not. Being a good citizen means the company operates in the light of social and environmental sensitivity without neglecting their responsibility to other stakeholders who prioritize financial performance of the company.

Eventhough, the company profile, company size and leverage are demonstrated to influence the disclosure of CSR in annual reports, the managers are the key to make it happen. CSR can be considered as an investment for the company. Hence, the benefits will come in the long run. While many researches have shown that CSR does not always relate to company profitability in the short run, ethical behavior will be the one approach which can guide all managers in ensuring the company becomes a good citizen in the long term.

The government legislation can not enforce the company to be socially responsible. There should be a minimum requirements that all companies have to comply with. The state owned companies are designed to be the leaders in conducting CSR projects in order to influence the private companies conducting CSR in their on scope and context.

\section{Limitations of the Study}

This research faced several limitations that come from the lack of available data. This research only involved 86 out of 317 companies listed in IDX during 2009 - 2012. In reality, this number is only $22 \%$ of the company who revealed the existence of CSR, so the level of generalizability is also greatly reduced. Besides these limitations, the three independent variables used in this research can only explain small variations of disclosure of CSR. In the next future, research on the same topic may add other variables that might better explain the 
variation of the disclosure of corporate social responsibility.

\section{REFERENCES}

Ahmed, B. and PG. Karpik. 1989. Determinant of the Corporate Decision to Disclose Social Information. Accounting, Auditing and Accountability Journal. 2(1). 36-51.

Anggraini, Fr. dan R. Retno. 2006. Pengungkapan Informasi Sosial dan Faktor-faktor yang Mempengaruhi Informasi Sosial dalam Laporan Keuangan Tahunan (Studi Empiris pada Perusahaanperusahaan yang terdaftar di Bursa Efek Jakarta). Simposium Nasional Akuntansi IX. Padang.

Brigham, E.F. dan JF. Houston. 2013. Fundamentals of Financial Management, Thirteenth Edition. South-Western Cengage Learning.

Cuganesan, S., L. Ward and J. Guthrie. Legitimacy Theory: A Story of Reporting Social and Environmental Matters within the Australian Food and Beverage Industry (July 5, 2007). Presented to the 5th Asian Pacific Interdisciplinary Research in Accounting (APIRA) Conference, 8-10 July 2007, Auckland, New Zealand. Available at SSRN: http://ssrn.com/abstract=1360518

DuBrin, A.J. 2012. Essentials of Management, Ninth Edition. South-Western, Mason, USA

Fathurohmi, H.N. 2010. Pengaruh Karakteristik Perusahaan terhadap Pengungkapan Corporate Social Responsibility dalam Laporan Tahunan Perusahaan (Studi Empiris pada Perusahaan yang terdaftar di Bursa Efek Indonesia Periode 2008). Skripsi. Universitas Teknologi Yogyakarta.

Fitriani. 2001. Signifikansi Perbedaan Tingkat Kelengkapan Pengungkapan Wajib dan Sukarela pada Laporan Keuangan Publik yang terdaftar di Bursa Efek Jakarta. Simposium Nasional Akuntansi IV. Bandung.
Flammer, C. 2013. Does Corporate Social Responsibility Lead to Superior Financial Performance? A Regression Discontinuity Approach. MIT Sloan Management Review.

Hackston, D. dan JM. Markus. 1996. Some Determinants of Social and Enviromental Disclosure in New Zealand Companies. Accounting, Auditing dan Accountability Journal. 9(1). 77 - 108.

Handayani, N.N. 2006. Pengaruh Karakteristik Perusahaan terhadap Luas Pengungkapan Sukarela Dalam Laporan Tahunan (Studi Empiris pada Perusahaan yang tercatat di BEJ). Skripsi. Universitas Teknologi Yogyakarta.

Hawkins, D.E. 2006. Corporate Social Responsibility: Balancing Tomorrow's Sustainability And Today's Profitability. PALGRAVE MACMILLAN. New York.

Jeremy, G. 2010. How does corporate social responsibility benefit firms? Evidence from Australia. European Business Review. 22(4). 411-431.

Kapoor, S. and H.S. Sandhu. 2010. Does it Pay to be Socially Responsible? An Empirical Examination of Impact of Corporate Social Responsibility on Financial Performance. Global Business Review. 11. 185-

Khan, R.M. 2013. Relationship between Financial Performance and CSR Activities in Companies In Pakistan. Interdiciplinary Journal of Contemporary Research in Business. 4(10).

Khan, R.M. and A. Hassan. 2013. Relationship Between Financial Performance and CSR Activities in Companies in Pakistan. Interdisciplinary Journal of Contemporary Research in Busines. 4(10). $918-928$.

Kunianto, N. 2007. Faktor-faktor yang Mempengaruhi Kelengkapan Pengungkapan Laporan Keuangan Pada Perusahaan manufaktur yang tercatat di Bursa Efek Jakarta. Skripsi. Universitas Teknologi Yogyakarta. Yogyakarta. 
Madura, J. 2007. Introduction to Business, Fourth Edition. Thomson SouthWestern: Canada

Mardiana, E. 2005. Analisis Pengaruh Struktur Modal, Tipe Kepemilikan Perusahaan, Profitabilitas dan Likuiditas terhadap kelengkapan Pengungkapan Laporan Keuangan. Skripsi. UPN Veteran Yogyakarta. Yogyakarta.

Marwata. 2000. Hubungan antara Karakteristik Perusahaan dan Kualitas Ungkapan Sukarela dalam Laporan Keuangan Tahunan Perusahaan Publik di Indonesia. Jurnal Ekonomi dan Bisnis. XII(1). 6787.

Maurice, B. et al. 2009. Sustainability and Competitive Advantage. MIT SLOAN MANAGEMENT REVIEW FALL. 51(1). $19-26$.

McWilliams, A. and D. Siegel. 2001. Corporate Social Responsibility: A Theory of the Firm Perspective. Academy of Management Review, 26(1):117-127.

Mirfazli, E. 2008. Evaluate corporate social responsibility disclosure at Annual Report Companies in multifarious group of industry members of Jakarta Stock Exchange (JSX), Indonesia. Social Responsibility Journal. 4(3). 388 - 406.

Na'im, A. dan F. Rachman. 2000. Analisis Hubungan Antara Kelengkapan Pengungkapan Laporan Keuangan dengan Struktur Modal dan Tipe Perusahaan. Jurnal Ekonomi dan Bisnis Indonesia. 15(1). 70-82.

Nisya Nur, A. 2008. Praktek Pengungkapan Sosial pada Laporan Tahunan di Perusahaan di Indonesia. Jurnal Ekonomi.

Park, S.Y. and S. Lee. 2009. Financial rewards for social responsibility: a mixed Picture for Restaurant Companies. Cornell Hospitality Quarterly. 50(2). 168-179.

Polinsky, A.M. and S. Shavell. 2010. Mandatory Versus Voluntary Disclosure of Product Risks. The Journal of Law, Economics, \& Organization. 28(2). 360-379.
Porter, M.E. and MR. Kramer. 2002. The Competitive Advantage of Corporate Philanthropy. Harvard Business Review, December 2002

Porter, M.E. and MR. Kramer. 2002. The Competitive Advantage of Corporate Philanthropy. Harvard Business Review. December 2002.

Reverte, C. 2009. Determinants of Corporate Social Responsibility Disclosure Ratings by Spanish Listed Firms. Journal of Business Ethics. 88(2). 351-366.

Robbins, S.P. and M. Coulter. 2012. Management, 11th ed. Pearson Education, Inc., Prentice Hall, Upper Saddle River, New Jersey

Sari, A.P. 2010. Pengaruh Tipe industri dan Rasio Keuangan terhadap Penungkapan Tanggung jawab Sosial Perusahaan. Skripsi. UTY.

Schermerhorn, J.R. Jr. 2012. Exploring Management. Third Edition. John Wiley \& Sons, Inc. United States of America.

Sembiring, E. 2005 Karakteristik Perusahaan dan Pengungkapan Tanggung Jawab Sosial: Studi Empiris pada Perusahaan yang Tercatat di Bursa Efek Jakarta. Simposium Nasional VIII, Solo.

Simanjuntak, B.H., Widiastuti dan Lusi. 2006. Karakteristik Perusahaan dan Pengungkapan Tanggung Jawab Sosial: Studi Empiris pada Perusahaan yang Terdaftar di Bursa Efek Jakarta. Jurnal Maksi. 6(1). 69 - 85.

Suchman, M. C. 1995. Managing Legitimacy: Strategic and Institutional Approaches. The Academy of Management Review. 20(3). 571-61.

Sujianto. 2001. Dasar-dasar management Keuangan. Yogyakarta: BPFE

Suripto, B. 1999. Pengaruh karakteristik Perusahaan terhadap Luas Pengungkapan Sukarela dalam Laporan Keuangan Tahunan. Simposium nasional Akuntansi II IAI-KAPd.

Susanne, A. 2011. Disclosure of non-financial information in the annual report: A 
management-team perspective. Journal of Intellectual Capital. 12(2). 277-300.

Udayasankar, K. 2007. Corporate Social Responsibility and Firm Size. Journal of Business Ethics. Available at SSRN: http://ssrn.com/abstract=1262535
Yintayani, N.N. 2011. Faktor-Faktor yang Memengaruhi Corporate Social Responsibility. Thesis of Magister Program at Udayana University, Denpasar. 